\title{
Transvestite:
}

\section{Tourism Law Perspective}

\author{
Murry Darmoko \\ Faculty of Law \\ Bhayangkara University of Surabaya \\ Surabaya, Indonesia \\ murry@ubhara.ac.id
}

\begin{abstract}
This research focuses on transvestite in tourism law perspective. The purpose of this research is to examine transvestite in tourism law perspective. This research follows IMRAD Structure in reporting, preceded by an abstract and followed by the conclusion. Method is descriptive, which studies word of transvestite in tourism law perspective. Results show that word transvestite is not written on any regulations of tourism in Indonesia, but they are existing in the real tourism life, and their activities can be related to the Fatwa MUI number 57 of 2014. Discussion shows some reasons why the transvestite word not exist in written regulations in Indonesia, but transvestite are treated under different customary laws in places such as Aceh and Thailand for comparison with different handling. Conclusion of this research tells transvestite are men in the status as a citizen (unless that has been granted turned into a female in court), and input for the Indonesian government is to immediately implement the MUI Fatwa convention in the regulations relating to transvestite as a preventive and repressive act in law enforcement in Indonesia to provide legal certainty of tourism in Indonesia.
\end{abstract}

Keywords - transvestite; law on tourism; fatwa MUI

\section{INTRODUCTION}

In Indonesia, the term transvestite is a combination of female-male abbreviations, a man dressed and wanting to be treated like a woman, styled in feminine look and wearing women's wigs and accessories), controversial genders in costumes. This is also called: transvestite, transgender and transvestite, but in this paper, I use the term 'transvestite' for the characteristics of its mention in Indonesia.

Transgenders are accepted by people who believe that human rights are the responsibility of every individual with the same rights and duties as any other individual. Transvestite are rejected by people who believe that transvestite are a mistake (health, psychology, social and religious) that must be corrected or even if necessary, destroyed. Transgender, in certain cases, raises the pros and cons of social problems in Indonesia including in the perspective of tourism law which in recent years is influenced by the presence of transvestite.

\section{METHOD}

The study of the existence of the term 'transvestite' references is carried out from January to February 2018 through Tourism Act No. 10 of 2009 as the primary source and media report as a secondary source in this paper. The subject of this study was obtained from transsexuals in Bali as sex tourism destination and transgender Aceh as a comparison then compared again with transvestite in Thailand. In the next step, the author studies transvestite with the approach of legal sociology using the paradigm of social definition theory. This paradigm states that the individual is more dominant and coercive in the behaviors undertaken and not necessarily does not follow the rules generally accepted [1]. Thus the laws or regulations imposed on transvestite vary from general laws or regulations that apply to male and female sexual orientation. Found to find that one transvestite with another formed a tourism network that helped each other in showing their existence. Their networks are formed on an exclusive minority base group that distinguishes individual identity and sexual orientation.

\section{RESULT AND DISCUSSION}

\section{A. Transvestite are Unpunishable}

The term transvestite is not found in the Law on Tourism No. 10 of 2009 and other laws and regulations. In government administration, the word transvestite is not written in the Birth Certificate (Akta Lahir), Identity Card (KTP), Driver's License (SIM), and Family Card (KK) as well as grave tombstones. Easily known that is Indonesian law and its regulations cannot bind, coerce and give sanction transvestite because the word transvestite is not written in all existing regulations. And consequently, transvestite have no right to claim rights and perform duties such as men and women. The interpretation said that citizens in Indonesia, always returned to the gender of men or women, not on transvestite.

Transvestites do not exist legally, but the fact that transvestites are the real thing that happens in everyday life. The evidence is that transvestite can be booked and found in several places and events and now, online. If we type in google the word 'transvestite', there are many related options appear in a result as 343.000 (0.88 seconds). In order to facilitate customers' booking, transvestites have a wide range of social media networks. And they are, usually exist in tourist location as Kuta, Legian, Seminyak, Tuban, Denpasar, Buleleng and Gianyar [2]. 


\section{B. Why Transvestite is Considered a Problem?}

It is important to explain why transvestites are not recognized in laws and regulations. First, Indonesia does not recognize the third sex. Secondly, even if there is no transvestite word and the acknowledgment of their existence, the transvestites' deeds can be regarded as a problem (by offering tourism sexual fantasy) as it is considered to be undermining Article 25 of the Tourism Act no. 10 Year 2009. The article confirms:

Every tourist is obliged to:

- preserve and respect the religious norms, customs, cultures, and values living in the local community;

Transvestite is a problem that must be solved with a winwin solution without ignoring the human rights of transvestite. Law as commander in maintaining the stability and comfort of society from conflicts on transvestite to be better society in every sector related to the law, including one the tourism sector, especially how transvestites are positioned and obtain legal certainty in a governmental setting.

\section{Transvestite in Aceh and Thailand: Comparisons}

Unlike the case in Aceh that implements Sharia Law, the news about transvestite in these weeks (when this research was written) became viral news. Untung Sangaji, North Aceh Police Chief, conducted a raid and arrested 12 transvestites [3] in two sub-districts on Saturday 27th of January 2018 and made them back (the netted raid) to 'macho', by shaving their hair and replacing their clothes in collared shirt men and make them run screaming until their male voice out [4]. A guidance that made the Chief of Police Chief examined by 'Propam' [5] and received responses from national figures, the spotlight of international amnesty and KOMNAS HAM which were 'vilified' by the owners and salon workers who lost their jobs in Aceh [6]. However, Untung's attitude was defended by the people of Aceh, including the Governor of Aceh (Irwandi Yusuf) and the Chairman of the Aceh House (Muharuddin). Even Untung was rewarded with rencong by YARA (Yayasan Advokasi Rakyat Aceh) [7]. On this occurrence, two slogans emerged: "Fortunately, there was Mr. Untung" [8] and rencong is rencong land, not a bencong land" [9].

To specify the scope of discussion, I used data from Wikipedia related to Thailand LGBT [10]. Another case in Bangkok Thailand, transvestites or katoeys or ladyboy get freedom of expression and become a tourist icon of Thailand. There are 10 ways to spot a ladyboy, which is 10 hotels featuring shows performed by Ladyboy [11].

The history of katoeys itself can be summarized as follows:

- Since 1956 legal sodomy for adult men.

- Since 2002 the ministry of health abolished homosexuality as a mental illness or psychiatric disorder.

- Since 2005 the Thai military lifted a ban on LGBT people to serve in the military.
- In 2009 Red Cross has banned MSM (Male Sex Male) providing blood donation, but there are campaigns to allow.

- Since 2015, anti-discrimination laws in employment.

\section{CONCLUSION}

After all the data and analysis results presented, ranging from introduction, method, results and discussion, there are two conclusions drawn in this paper: first, transvestites are men, although with all kinds of jewelry and behavior that they do, they remain the eye law. Secondly, the rules that apply in the law of tourism cannot ensnare transvestites in destroying existing regulations, especially those listed in Article 25 of the Tourism Law. 10 of 2009, therefore, it is recommended that the government adopt MUI fatwa number 57 year 2014 which provides legal certainty about deviant behavior done by transvestites in the process of preventive and repressive punishment in the form of rehabilitation to death.

Next researchers, who are interested in transvestite issues, are recommended to examine the role of transvestites in fighting for human rights in the field of law and health in an effort to prevent HIV-AIDS and the religious pattern of transvestites in facing the challenges of life in Indonesia.

\section{ACKNOWLEDGEMENT}

The author would like to thank all the parties who have helped and contributed in the writing of this article, both those who contribute in the form of funding and critical ideas. Hopefully this paper can be useful theoretically and practically for the addition and development of knowledge, especially in the field of legal science.

\section{REFERENCES}

[1] Murry, D. M., Modul Kuliah Sosiologi Hukum Fakultas Hukum UBHARA Surabaya, Surabaya: Ubhara Press, 2017.

[2] Yayasan Gaya Dewata, Tempat Nongkrong di Bali www.gayadewata.com/lgbt-hidup-di-bali/tempat-nongkrong/ 2018.

[3] M. Sohuturon, Tangkap 12 Transvestite, Kapolres Aceh Utara diperiksa Propam, CNN Indonesia (News of Thursday, February 1, 2018, at 09:44 WIB posted on the website: https:/m.cnnindonesia)

[4] D. H. Molana, Bantah gunduli transvestite, Kapolres Aceh Utara: Cuma Pangkas biar Macho, detikNews (News of Thursday, February 1, 2018, at 21:16 WIB posted on the website: https:/m.detik.com)

[5] R. Umar, Cukur rambut transvestite saat razia, Kapolres Aceh Utara diinvestigasi Polda Aceh, Kompas (News of Friday, February 2, 2018, at 07:46 WIB posted on the website: regional.kompas.com)

[6] S. Lestari, Penangkapan 'transvestite' di Aceh Utara sebabkan hilangnya pekerjaan, BBC Indonesia (News of Wednesday, January 31, 2018, posted on the website: www.bbc.com/indonesia)

[7] A. Gultom, Tegas menindak transvestite, Kapolres Aceh Utara dihadiahi rencong, RMOL January 31, 2018

[8] E. Fitriady, Transvestite in mendadak macho, lari kencang sekali, kejarkejaran 1 menit dengan Satpol PP Banda Aceh, Serambi Indonesia, (News of Friday, February 2, 2018, at 17:02 WIB posted on the website: aceh.tribunnews.com) 
[9] Fzi, Ini tanah rencong bukan tanah bencong, Ormas Islam Aceh tolak LGBT, Tagar News (News of Friday, February 2, 2018, at 17:21 WIB posted on the website: www.tagar.id)
[10] Wikipedia, LGBT Rights in Thailand, available at: https://en.wikipedia.org/wiki/LGBT_rightsinThailand\#citenote-32 2018. Bangkok.com, 10 Ways to Spot a Ladyboy, available at: www.bangkok.com/magazine/ladyboys.html 2018. 